\title{
Population Genetic Structure of Helix pomatia L. (Mollusca, Pulmonata) from the Southeastern and Eastern Parts of the Range
}

\author{
E. A. Snegin* and O. Yu. Artemchuk \\ Belgorod State National Research University, Belgorod, 308015 Russia \\ *e-mail:snegin@bsu.edu.ru \\ Received April 7, 2016; in final form, August 10, 2016
}

\begin{abstract}
On the basis of the analysis of genetic variation detectable by ISSR-PCR, the state of the gene pools of 14 populations of Roman snail Helix pomatia $\mathrm{L}$. in the conditions of urbanized landscapes of the southeastern and eastern parts of the current range was examined. According to the data obtained, the majority of the studied populations of this mollusk are in satisfactory condition. This is evidenced by the increased level of genetic diversity $\left(H_{\mathrm{e}}=0.199 \pm 0.025, I_{\mathrm{sh}}=0.306 \pm 0.035\right)$ and the high values of effective population size, calculated, on the basis of the straight-line regression equation, between the pairwise genetic and geographic distances $(\mathrm{Ne}=2.0-4.9)$ that are comparable with indigenous common species of terrestrial mollusks. Despite the high level of differentiation $\left(G_{\mathrm{st}}=0.255, \Phi_{\mathrm{st}}=0.233, \mathrm{Nm}=0.822\right)$, the population distribution was not random $\left(R_{\mathrm{m}}=-0.591, p=0.0004\right)$ and corresponded to the model of isolation by distance. It is hypothesized that, in the adventitious colonies of this mollusk, effective formation of a balanced genetic structure takes place that, in the context of biological and ecological features, facilitates its adaptation to the conditions of an urban environment and the population of the new territories of Eastern Europe.
\end{abstract}

Keywords: population gene pool, DNA, terrestrial mollusk, Helix pomatia, urbanized landscape

DOI: $10.1134 / \mathrm{S} 1022795417030127$

\section{INTRODUCTION}

Roman snail (Helix pomatia Linnaeus, 1758) is one of the largest land snails. The initial species range and, apparently, the center of origin of this species are the regions of Central and Southeastern Europe. The modern range of Roman snail, due to the introduction, covers the Volga region, western regions of Belarus, Ukraine, and the Baltic states, including Kaliningrad [1-3]. In addition, the mollusk has been introduced in a number of cities such as St. Petersburg, Kursk, Moscow, and Kharkiv [4-7]. There are reports on introduction of H. pomatia in Finland [8] and the United States [9], where currently the species is registered in the American Malacological Bulletin on the list of North American terrestrial gastropods [10].

In addition to the settlements where this species was introduced, in some regions, its populations naturalized in natural forest communities with environmental or cultural-historical status. The result of the introduction of $H$. pomatia into alien biogeocoenoses, but as it turned out, quite suitable for naturalization of this species, was the emergence of multiple, geographically isolated populations of Roman snail that are good objects in the studies of microevolutionary phenomena occurring in modern urban landscapes.
Traditionally, large animals, which include Roman snail, attract more attention upon the development of the measures for their protection in the wild. Some authors have attributed this species to the category of species of special concern [11]. At present, Roman snail is listed in the Convention on the Conservation of European Wildlife and Natural Habitats (Bern Convention), Annex III: Protected Fauna Species (September 19, 1979), as well as in the Council Directive (EU Habitats Directive Annex Va) 92/43/EEC of January 1, 2007. The current conservation status of the world macropopulation of $H$. pomatia as of 2015 at the IUCN website (http://www.iucn.org) is designated as LC (least concern) status, i.e., a species with minimal threats to its existence [12]. Nevertheless, in certain local territories, the species is the subject of protective legislation. The species is included in the lists of threatened species of Denmark, Great Britain, Latvia, Bulgaria, and Estonia. In Ukraine, it is included in the Red Book of Sumy oblast [13]. In Russia, this species is listed in the Red Book of Belgorod and Voronezh oblasts $[14,15]$ and is recommended for inclusion in the Red Book of Samara oblast [16].

Apparently, the exact number of currently existing geographically isolated populations of $H$. pomatia is not known, but some of them are objects for ecological 


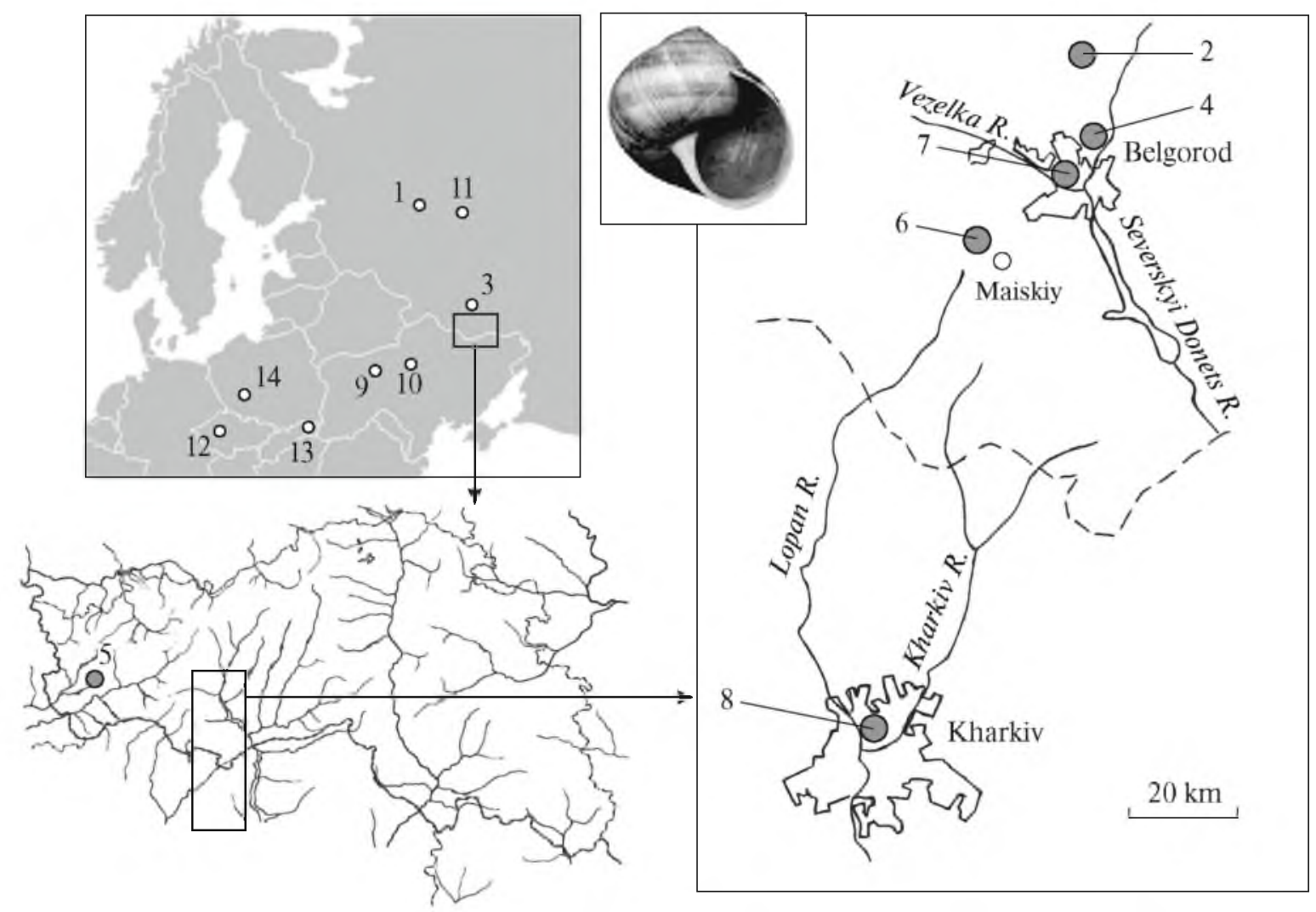

Fig. 1. Sampling sites of Helix pomatia (the sampling site description is shown in Table 1).

and genetic studies. Some studies were focused on the analysis of the population structure of this species on the basis of the analysis of morphological characters [17-20] and allozyme markers [21-23].

In our previous studies, the Roman snail population structure in the area of investigation was described by conchological traits and allozymes [24, 25]. However, the use of these definitely important markers of the population structure has a number of limitations. First, in this mollusk, metric traits of the shell are not discrete and are subjected to modification variability, which does not make it possible to trace the genetic processes occurring in studied groups. Secondly, it is known that the shell phenes and isoenzymes reflect variability of only the coding part of the genome, which, according to various estimates, constitutes about $10 \%$ of total DNA, while the rest, the socalled silent (satellite) DNA, remains out of the question. At the same time, these regions contain a great number of selectively neutral sites, which can be traced for the genetic automatic processes in the populations. The most convenient way to solve this problem is the use of ISSR DNA markers (inter simple sequence repeats) [26], the use of which is based on the use of a primer having multiple complementary regions containing tandem repeats scattered throughout the genome. Earlier, we carried out the preliminary analysis of five Roman snail populations using two ISSR primers, which made it possible to estimate the state of the gene pools of the studied groups living in urban environment areas of the southeastern part of the current range [27]. Later on, these studies were continued.

The objective of this study was to analyze the population structure of $H$. pomatia in the conditions of Eastern European urban landscapes using DNA markers (ISSR) to study the microevolution phenomena occurring in the populations of the species.

\section{MATERIALS AND METHODS}

The experiments were performed using tissue specimens of Helix pomatia L., stored in the cryobank created at the Laboratory of Population Genetics and Genetoxicology, Belgorod State National Research University. Population samples were collected during the expeditions from 2006 through 2015. At the DNA loci, a total of $511 \mathrm{H}$. pomatia individuals from 14 populations were examined (Fig. 1, Table 1).

DNA was extracted from mantle specimens thoroughly removed from mucus. DNA was isolated using silica-based sorbent according to the instructions to the Silica uni reagent kit (Biokom, Russia). Amplification was carried out in thermal cyclers MJ Mini and MyCycler (Bio-Rad, United States). The reactions 
Table 1. Description of the sampling sites

\begin{tabular}{|c|c|c|c|}
\hline Site & $N$ & Site description & Coordinates \\
\hline 1. Tver & 7 & Tver, old park in the area of car-building factory & $\begin{array}{l}56^{\circ} 51^{\prime} 41.65^{\prime \prime} \mathrm{N} \\
35^{\circ} 54^{\prime} 11.28^{\prime \prime} \mathrm{E}\end{array}$ \\
\hline 2. Shopino & 24 & $\begin{array}{l}\text { Belgorod oblast, Belgorod raion, settlement of Shopino, ravine forest near the Bel- } \\
\text { gorod-Moscow route }\end{array}$ & $\begin{array}{l}50^{\circ} 42^{\prime} 59.37^{\prime \prime} \mathrm{N} \\
36^{\circ} 29^{\prime} 29.98^{\prime \prime} \mathrm{E}\end{array}$ \\
\hline 3. Kursk & 15 & Kursk, forest area adjacent to a garage and a dump of construction waste & $\begin{array}{l}51^{\circ} 45^{\prime} 24.44^{\prime \prime} \mathrm{N} \\
36^{\circ} 08^{\prime} 28.95^{\prime \prime} \mathrm{E} \\
\end{array}$ \\
\hline 4. Donets & 42 & $\begin{array}{l}\text { Floodplain of Severskyi Donets River, near the city of Belgorod. Thickets of willow } \\
\text { and maple. Common burdock, nettle }\end{array}$ & $\begin{array}{l}50^{\circ} 36^{\prime} 38.40^{\prime \prime} \mathrm{N} \\
36^{\circ} 37^{\prime} 19.19^{\prime \prime} \mathrm{E} \\
\end{array}$ \\
\hline 5. Hotmizhsk & 29 & $\begin{array}{l}\text { Belgorod oblast, settlement of Hotmizhsk floodplain of the Vorskla River, ravine forest } \\
\text { near the Church of the Resurrection, recreational area of the Krasivo health spa }\end{array}$ & $\begin{array}{l}50^{\circ} 35^{\prime} 26.00^{\prime \prime} \mathrm{N} \\
35^{\circ} 54^{\prime} 11.28^{\prime \prime} \mathrm{E}\end{array}$ \\
\hline 6. Maiskiy & 115 & Belgorod oblast. Belgorod raion, settlement of Maiskiy ravine oak forest & $\begin{array}{l}50^{\circ} 30^{\prime} 59.26^{\prime \prime} \mathrm{N} \\
36^{\circ} 27^{\prime} 15.98^{\prime \prime} \mathrm{E} \\
\end{array}$ \\
\hline 7. Belgorod & 65 & $\begin{array}{l}\text { Belgorod, willow forest in the floodplain of the Vezelka River, near the campus of } \\
\text { Belgorod State Research University. Of plants: nettle, common burdock, cleavers, } \\
\text { dandelion }\end{array}$ & $\begin{array}{l}50^{\circ} 35^{\prime} 39.17^{\prime \prime} \mathrm{N} \\
36^{\circ} 34^{\prime} 04.49^{\prime \prime} \mathrm{E}\end{array}$ \\
\hline 8. Kharkiv & 68 & Kharkiv (Ukraine), Taras Shevchenko city park, floodplain of the Lopan River & $\begin{array}{l}50^{\circ} 00^{\prime} 15.72^{\prime \prime} \mathrm{N} \\
36^{\circ} 13^{\prime} 31.31^{\prime \prime} \mathrm{E} \\
\end{array}$ \\
\hline 9. Zhytomyr & 35 & $\begin{array}{l}\text { Zhytomyr (Ukraine) Parkland of the Teterev River floodplain; on the opposite side } \\
\text { of the river is the Gagarin city park of culture and recreation }\end{array}$ & $\begin{array}{l}50^{\circ} 14^{\prime} 19.27^{\prime \prime} \mathrm{N} \\
28^{\circ} 40^{\prime} 07.79^{\prime \prime} \mathrm{E} \\
\end{array}$ \\
\hline 10. Kyiv & 28 & Kyiv (Ukraine), Fomin Botanical Garden & $\begin{array}{l}50^{\circ} 24^{\prime} 52.38^{\prime \prime} \mathrm{N} \\
30^{\circ} 33^{\prime} 29.29^{\prime \prime} \mathrm{E} \\
\end{array}$ \\
\hline 11. Bykovo & 23 & $\begin{array}{l}\text { Moscow oblast, Ramenskii raion, settlement of Bykovo, territory of All-Russian } \\
\text { Center for Plant Quarantine. Mixed forest with a predominance of Scots pine }\end{array}$ & $\begin{array}{l}55^{\circ} 38^{\prime} 11.43^{\prime \prime} \mathrm{N} \\
38^{\circ} 06^{\prime} 02.81^{\prime \prime} \mathrm{E}\end{array}$ \\
\hline 12. Prague & 20 & $\begin{array}{l}\text { City of Mochov, near Prague (Czech Republic). Agricultural landscape, close to } \\
\text { the railway. Thickets of black elderberry }\end{array}$ & $\begin{array}{l}50^{\circ} 08^{\prime} 12.677^{\prime \prime} \mathrm{N} \\
14^{\circ} 47^{\prime} 38.217^{\prime \prime} \mathrm{E} \\
\end{array}$ \\
\hline 13. Bukovce & 20 & $\begin{array}{l}\text { Surroundings of Bukovce (Slovakia), along the road to the settlement of Chotca. } \\
\text { Deciduous forest. Thickets of fern-leaved chervil, nettle }\end{array}$ & $\begin{array}{l}49^{\circ} 15^{\prime} 41.59^{\prime \prime} \mathrm{N} \\
21^{\circ} 41^{\prime} 39.41^{\prime \prime} \mathrm{E} \\
\end{array}$ \\
\hline 14. Wrocław & 20 & Suburbs of Wrocław (Poland). Deciduous forest (oak, maple), along Oder River & $\begin{array}{l}51^{\circ} 08^{\prime} 47.40^{\prime \prime} \mathrm{N} \\
16^{\circ} 57^{\prime} 36.72^{\prime \prime} \mathrm{E}\end{array}$ \\
\hline
\end{tabular}

were run in a total volume of $25 \mu \mathrm{L}$ of reaction mixture containing $20 \mathrm{ng}$ genomic DNA, PCR buffer $(67 \mathrm{mM}$ Tris- $\mathrm{HCl}(\mathrm{pH} 8.8), 16 \mathrm{mM}\left(\mathrm{NH}_{4}\right)_{2} \mathrm{SO}_{4}, 5 \mathrm{mM} \beta$-mercaptoethanol, $7 \mathrm{mM}$ EDTA, $3 \mathrm{mM} \mathrm{MgCl}$ ), $0.25 \mathrm{mM}$ dNTP, $0.5 \mu \mathrm{M}$ primer, and 1 unit of Taq DNA polymerase (inhibited for hot start). The reaction conditions consisted of one cycle of $2 \mathrm{~min} / 94^{\circ} \mathrm{C}$, followed by 40 cycles $\left(30 \mathrm{~s} / 94^{\circ} \mathrm{C}, 30 \mathrm{~s} / \mathrm{T}^{\circ} \mathrm{C}, 2 \mathrm{~min} / 72^{\circ} \mathrm{C}\right)$, and one cycle of $10 \mathrm{~min} / 72^{\circ} \mathrm{C}$. PCR was carried out with three primers designed at the University of British Columbia (set no. 9, www.michael-smith.ubc.ca). The primer sequences are shown in Table 2.

PCR products were separated by electrophoresis on a $2 \%$ agarose gel in TAE buffer (cooled to $4^{\circ} \mathrm{C}$ ) and at $10 \mathrm{~V} / \mathrm{cm}$ for $45 \mathrm{~min}$. The blocks were stained with ethidium bromide.

The amplified fragment patterns obtained in the course of electrophoresis were used for the construc- tion of binary matrices, where the band presence was designated as " 1 " (allele $p$ ) and the band absence was designated as " 0 " (allele $q$ ). In $H$. pomatia, a total of 57 loci were identified (Table 2). The resulting DNA patterns and their interpretation are shown in Fig. 2.

Analysis of molecular variance AMOVA [28] and the population genetic diversity indices, such as expected heterozygosity $\left(H_{\mathrm{e}}\right)$, the mean number of alleles per locus $(A)$, effective number of alleles $\left(A_{\mathrm{e}}\right)$, Shannon index $\left(I_{\mathrm{sh}}\right)$, and the percentage of polymorphic loci $(P \%)$, were calculated in the GenAlEx v. 6.5 software program [29]. In addition, this program was used to assess the correlation between the level of gene flow between groups and the level of pairwise genetic distances using the Mantel test $[30,31]$ and to calculate the Nei and Li genetic distances [32]. On the basis of the genetic distance matrix, clustering of the samples was performed using the unweighted pair-group 
Table 2. Primers used in the study

\begin{tabular}{l|c|c|c}
\hline \multicolumn{1}{c|}{ Primer } & Sequence $5^{\prime}-3^{\prime}$ & Annealing temperature, ${ }^{\circ} \mathrm{C}$ & Number of loci \\
\hline UBC-809 & $(\mathrm{AG})_{8} \mathrm{G}$ & 52 & 18 \\
$\mathrm{UBC}-811$ & $(\mathrm{GA})_{8} \mathrm{C}$ & 50 & 19 \\
$\mathrm{UBC}-827$ & $(\mathrm{AC})_{8} \mathrm{G}$ & 55 & 20 \\
\hline
\end{tabular}

method (UPGMA) [33] in the MEGA6 software program [34]. The degree of the population differentiation was assessed using the Nei model [35] as implemented in the POPGENE 32 software program [36]. Debets polygons were constructed using the Statistica 6.0 software program.

\section{RESULTS}

The parameters of genetic variation of the studied population are shown in Table 3 . According to the data obtained, there was no correlation between the genetic diversity and the geographical location of the snail groups. For instance, the most monomorphic group was the population of Kyiv (no. 10). A slightly higher level of genetic variation was observed in Kharkiv (no. 8). The highest average expected heterozygosity and Shannon index values were characteristic of the populations from the outskirts of Prague (no. 12) and Moscow (no. 11). The highest percentage of polymorphic loci was observed in the Donets (no. 4) and Belgorod (no. 7) populations. In addition, the Donets group was characterized by the highest average number of alleles per locus, and the population from the outskirts of Wrocław (no. 14) was the leading one among the examined groups in the effective number of alleles.

Analysis of molecular variance (AMOVA) [28] based upon the data for DNA loci (Table 4) revealed rather high genetic differentiation of the populations of $H$. pomatia. The differences between the populations accounted for $23 \%$ of the variation, while the differentiation index $\Phi_{\text {st }}$ was 0.233 and the gene flow parameter $N m$ was 0.822 individuals per generation. It should be noted that the values of these indices were somewhat different from those obtained by allozyme markers [25], wherein the ratio between the amongpopulation variance (Vap) and within-population variance $(V w p)$ was $29 / 71 \%$, with $\Phi_{\mathrm{st}}=0.291$ and $N m=0.609$.

In addition, the data of the molecular analysis of variance of the populations of $H$. pomatia at the DNA (a)

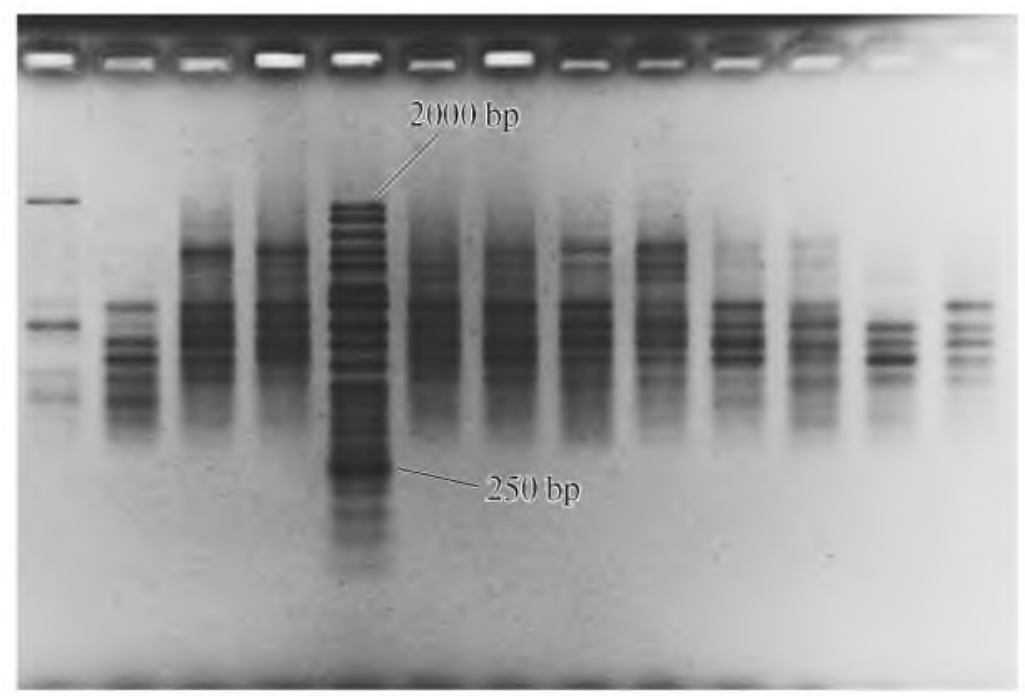

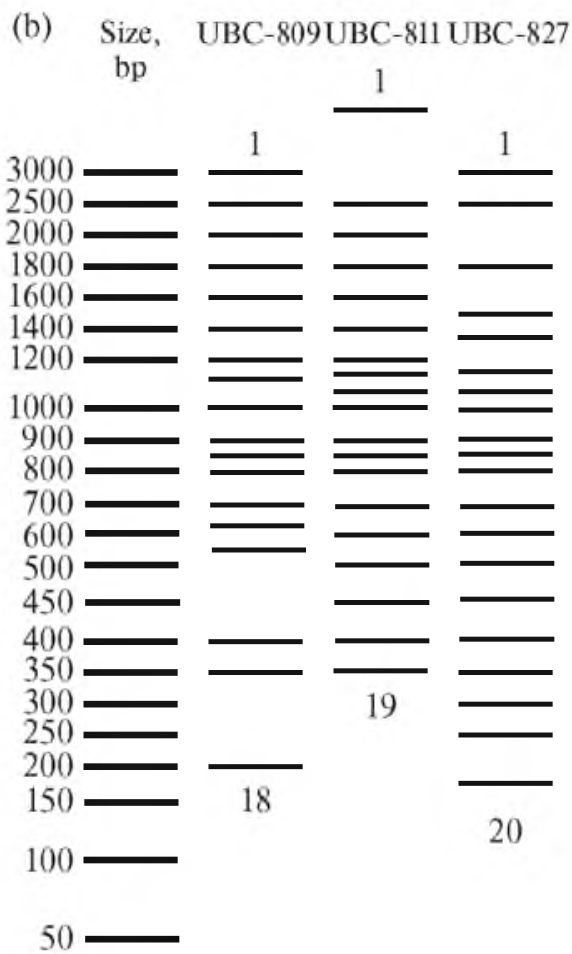

Fig. 2. Fragment of electrophoretogram with DNA patterns of $H$. pomatia obtained by using primer UBC 809 (a). Interpretation of the DNA patterns of $H$. pomatia (the numbers designate only the first and last loci) (b). 
Table 3. Measures of genetic heterogeneity in the populations of $H$. pomatia averaged over a set of DNA loci

\begin{tabular}{l|c|c|c|c|c|c}
\hline \multicolumn{1}{c|}{ Site } & $N$ & $P \%$ & $A$ & $A_{\mathrm{e}}$ & $H_{\mathrm{e}}$ & $I_{\text {sh }}$ \\
\hline 1. Tver & 7 & 49.12 & $1.491 \pm 0.067$ & $1.333 \pm 0.052$ & $0.188 \pm 0.028$ & $0.275 \pm 0.040$ \\
2. Shopino & 24 & 68.42 & $1.684 \pm 0.062$ & $1.323 \pm 0.051$ & $0.188 \pm 0.026$ & $0.288 \pm 0.036$ \\
3. Kursk & 15 & 64.91 & $1.649 \pm 0.064$ & $1.363 \pm 0.051$ & $0.210 \pm 0.027$ & $0.315 \pm 0.038$ \\
4. Donets & 42 & 89.47 & $1.895 \pm 0.041$ & $1.280 \pm 0.033$ & $0.192 \pm 0.019$ & $0.318 \pm 0.026$ \\
5. Hotmizhsk & 29 & 64.91 & $1.649 \pm 0.064$ & $1.327 \pm 0.048$ & $0.193 \pm 0.026$ & $0.293 \pm 0.037$ \\
6. Maiskiy & 115 & 80.70 & $1.807 \pm 0.053$ & $1.325 \pm 0.046$ & $0.197 \pm 0.025$ & $0.306 \pm 0.035$ \\
7. Belgorod & 65 & 87.72 & $1.877 \pm 0.044$ & $1.328 \pm 0.043$ & $0.207 \pm 0.022$ & $0.330 \pm 0.031$ \\
8. Kharkiv & 68 & 84.21 & $1.842 \pm 0.049$ & $1.262 \pm 0.036$ & $0.175 \pm 0.020$ & $0.287 \pm 0.029$ \\
9. Zhitomir & 35 & 63.16 & $1.632 \pm 0.064$ & $1.318 \pm 0.049$ & $0.187 \pm 0.026$ & $0.284 \pm 0.037$ \\
10. Kyiv & 28 & 50.88 & $1.509 \pm 0.067$ & $1.295 \pm 0.051$ & $0.169 \pm 0.027$ & $0.253 \pm 0.038$ \\
11. Bykovo & 23 & 82.46 & $1.825 \pm 0.051$ & $1.377 \pm 0.048$ & $0.226 \pm 0.025$ & $0.349 \pm 0.034$ \\
12. Prague & 20 & 78.95 & $1.789 \pm 0.054$ & $1.361 \pm 0.041$ & $0.227 \pm 0.023$ & $0.354 \pm 0.032$ \\
13. Bukovce & 20 & 59.65 & $1.596 \pm 0.065$ & $1.354 \pm 0.051$ & $0.205 \pm 0.027$ & $0.306 \pm 0.038$ \\
14. Wrocław & 20 & 59.65 & $1.596 \pm 0.065$ & $1.383 \pm 0.050$ & $0.222 \pm 0.27$ & $0.329 \pm 0.039$ \\
\hline Mean & \multicolumn{7}{|c|}{$70.30 \pm 3.60$} & $1.701 \pm 0.058$ & $1.331 \pm 0.046$ & $0.199 \pm 0.025$ & $0.306 \pm 0.035$ \\
\hline
\end{tabular}

Table 4. Molecular variance (AMOVA) values at the DNA loci in the populations of $H$. pomatia

\begin{tabular}{l|c|c|c|c|c|c|c|c}
\hline \multirow{2}{*}{ Source of variation } & $\begin{array}{c}\text { Number of degrees } \\
\text { of freedom }(d . f .)\end{array}$ & $\begin{array}{c}\text { Sum of } \\
\text { squares }(S S)\end{array}$ & $\begin{array}{c}\text { Mean square } \\
(M S)\end{array}$ & $\begin{array}{c}\text { Variance } \\
(V)\end{array}$ & $\%$ & $\Phi_{\text {st }}$ & $P$ & \multirow{2}{*}{$N m$} \\
\hline Between the populations & 13 & 1030.93 & 79.303 & 2.076 & 23 & & & \multirow{2}{*}{0.822} \\
\hline Within the populations & 497 & 3403.27 & 6.848 & 6.848 & 77 & 0.233 & 0.01 & 0.822 \\
\hline Total & 510 & 4434.207 & 86.150 & 8.924 & & & & \\
\hline
\end{tabular}

markers were similar to those obtained previously for indigenous common species of mollusks Bradybaena fruticum Müll. and Chondrula tridens Müll., living in the south of the Central Russian Upland. For example, in Br. fruticum at the DNA loci, the level of population differentiation $\Phi_{\text {st }}=0.298$, the gene flow parameter $N m=0.708$, and $\operatorname{Var} / V w p=30 / 70 \%$. In Ch. tridens, $\Phi_{\mathrm{st}}=0.185, \mathrm{Nm}=0.954$, and $\mathrm{Var} / \mathrm{Vwp}=$ $19 / 81 \%$ [37]. The level of genetic differentiation of Roman snail populations was considerably lower than that of the populations of the relict mollusk Helicopsis striata Müll. $\left(\Phi_{\mathrm{st}}=0.404, \mathrm{Nm}=0.360, \mathrm{Var} / \mathrm{V} w \mathrm{p}=\right.$ $40 / 60 \%$ ), also found in the study area [38].

The pairwise $\Phi_{\text {st }}$ estimates of genetic differentiation obtained on the basis of 57 ISSR loci are shown in Table 5. It is noteworthy that the pairwise $\Phi_{\mathrm{st}}$ values of genetic differentiation between western groups (sites 12 , 13 , and 14) in $56 \%$ of cases exceeded the corresponding values calculated between eastern colonies.

The degree of differentiation of the studied populations of $H$. pomatia at different loci estimated using the Nei model [35] showed a pattern similar to the AMOVA parameters. For instance, the proportion of interpopulation gene diversity in total diversity $G_{\text {st }}=$
0.255 , while the expected proportion of heterozygous genotypes in total population $H_{\mathrm{T}}=0.267 \pm 0.030$, and the value intrapopulation diversity averaged over all subpopulations was $\overline{H \mathrm{~s}}=0.199 \pm 0.017$.

It is known that the average $G_{\text {st }}$ values correspond to the level of genetic differentiation observed in the selectively neutral process. In this case, the loci with higher $G_{\mathrm{st}}$ values most likely experience a disruptive selection, while the loci with low subdivision index values are affected by stabilizing selection [39]. According to the data obtained, the maximum differentiation between populations was observed at the UBC-809-16 $\left(G_{\mathrm{st}}=0.485\right)$, UBC-811-17 $\left(G_{\mathrm{st}}=\right.$ $0.760)$, and UBC-827-14 ( $\left.G_{\mathrm{st}}=0.470\right)$ loci, while the lowest differentiation was observed at the high molecular loci UBC-809-1 $\left(G_{\mathrm{st}}=0.009\right)$, UBC-811-1 $\left(G_{\mathrm{st}}=\right.$ $0.023)$, and UBC-827-1 ( $\left.G_{\mathrm{st}}=0.013\right)$.

It should be noted that our earlier analysis of the gene pools of five populations (sites 6-10) with two primers (UBC-827 and SAS-1) [27] showed that the average values of genetic heterogeneity parameters among these populations were higher than in the present study, both for the individual populations and in the average for all groups. However, the calculated 
Table 5. Pairwise genetic differentiation estimates $\left(\Phi_{\mathrm{st}}\right)$ between populations of $H$. pomatia at ISSR loci

\begin{tabular}{c|c|c|c|c|c|c|c|c|c|c|c|c|c|c}
\hline Site & 1 & 2 & 3 & 4 & 5 & 6 & 7 & 8 & 9 & 10 & 11 & 12 & 13 & 14 \\
\hline 1 & & 0.001 & 0.001 & 0.001 & 0.001 & 0.001 & 0.001 & 0.001 & 0.001 & 0.001 & 0.001 & 0.001 & 0.001 & 0.001 \\
\hline 2 & 0.506 & & 0.001 & 0.001 & 0.001 & 0.001 & 0.001 & 0.001 & 0.001 & 0.001 & 0.001 & 0.001 & 0.001 & 0.001 \\
\hline 3 & 0.493 & 0.197 & & 0.001 & 0.001 & 0.001 & 0.001 & 0.001 & 0.001 & 0.001 & 0.001 & 0.001 & 0.001 & 0.001 \\
\hline 4 & 0.368 & 0.265 & 0.224 & & 0.001 & 0.001 & 0.001 & 0.001 & 0.001 & 0.001 & 0.001 & 0.001 & 0.001 & 0.001 \\
\hline 5 & 0.470 & 0.100 & 0.122 & 0.252 & & 0.001 & 0.001 & 0.001 & 0.001 & 0.001 & 0.001 & 0.001 & 0.001 & 0.001 \\
\hline 6 & 0.442 & 0.169 & 0.182 & 0.211 & 0.145 & & 0.001 & 0.001 & 0.001 & 0.001 & 0.001 & 0.001 & 0.001 & 0.001 \\
\hline 7 & 0.320 & 0.154 & 0.184 & 0.084 & 0.151 & 0.099 & & 0.001 & 0.001 & 0.001 & 0.001 & 0.001 & 0.001 & 0.001 \\
\hline 8 & 0.372 & 0.266 & 0.265 & 0.093 & 0.251 & 0.182 & 0.076 & & 0.001 & 0.001 & 0.001 & 0.001 & 0.001 & 0.001 \\
\hline 9 & 0.451 & 0.345 & 0.309 & 0.228 & 0.325 & 0.198 & 0.185 & 0.197 & & 0.001 & 0.001 & 0.001 & 0.001 & 0.001 \\
\hline 10 & 0.468 & 0.398 & 0.395 & 0.308 & 0.406 & 0.281 & 0.223 & 0.232 & 0.136 & & 0.001 & 0.001 & 0.001 & 0.001 \\
\hline 11 & 0.413 & 0.222 & 0.179 & 0.130 & 0.187 & 0.171 & 0.118 & 0.191 & 0.328 & 0.378 & & 0.001 & 0.001 & 0.001 \\
\hline 12 & 0.332 & 0.379 & 0.359 & 0.140 & 0.377 & 0.336 & 0.197 & 0.203 & 0.313 & 0.347 & 0.232 & & 0.001 & 0.001 \\
\hline 13 & 0.419 & 0.376 & 0.325 & 0.301 & 0.345 & 0.339 & 0.264 & 0.299 & 0.404 & 0.451 & 0.282 & $\mathbf{0 . 3 7 2}$ & & 0.001 \\
\hline 14 & 0.461 & 0.394 & 0.354 & 0.267 & 0.374 & 0.343 & 0.271 & 0.300 & 0.352 & 0.422 & 0.260 & $\mathbf{0 . 3 1 8}$ & $\mathbf{0 . 2 5 7}$ & \\
\hline Bew & & & &
\end{tabular}

Below the diagonal are the $\Phi_{\mathrm{st}}$ estimates and above the diagonal is the level of their statistical significance; the $\Phi_{\mathrm{st}}$ values between western groups are in bold type.

average of means showed no considerable differences. A statistically significant difference was obtained only by the percentage of polymorphic loci $(89.33 \pm 5.71 \%$ versus $70.30 \pm 3.60 \%$ ). The level of differentiation of the five groups was lower $\left(G_{\mathrm{sl}}=0.166, \Phi_{\mathrm{sl}}=0.210\right)$.

The dendrogram of genetic distances and Debets polygons (radar charts) of the studied populations constructed using frequencies of $q$ allele are shown in Figs. 3 and 4. In some cases the data show a certain dependence of the degree of genetic similarity between populations on their geographical closeness, and it seems likely that, judging by this distribution, the relationships between adventitious colonies can be assessed. For instance, the Zhitomir and Kyiv groups appeared to be quite close (cluster 2). A single cluster also formed the populations belonging to the south of the Central Russian Upland (sites 2-8, cluster 1), which were divided into two groups. One group included the colonies living in Belgorod and Kharkiv, and the other group included the colonies from the city of Kursk and Belgorod oblast. The exception was only the snails from Moscow oblast (site 11, Bykovo), which also were placed in this group. However, the origin of this colony is unknown, and its relationships with more southern neighbors cannot be excluded.

Western groups from the Czech Republic (site 12), Slovakia (site 13), and Poland (site 14) (cluster 3) predictably have similar gene pools. The population from the city of Tver (site 1 ) was found to be genetically and geographically most distant from all other groups.

The sample clustering patterns are confirmed by the analysis of regression between the pairwise loga- rithm values of the gene flow between populations $(\log N m)$ and the logarithms of geographic distances between them $(\log D)$ (Fig. 5). Using the Mantel test, an inverse relationship between these parameters ( $R_{\mathrm{m}}=-0.591, P=0.0004,9999$ permutations) was established. It should also be noted that a similar result was obtained earlier using allozymes as genetic markers; however, the colony clustering patterns were somewhat different [25].

We also calculated the effective size of the studied colonies of $H$. pomatia on the basis of the model proposed by Slatkin [40], which is based on the equation of straight-line regression and the coefficients of the linear function between the pairwise estimates of gene flow $(\mathrm{Nm})$ and geographic distance $(D)$ between populations:

$$
\log N m=a+b \log D .
$$

The effective population size (for all studied populations as a whole) is calculated as $N e=10^{a}$, where $a$ is the coefficient obtained in the equation. The equation is shown in Fig. 5. The calculation results are shown in Table 6.

\section{DISCUSSION}

Given the fact that the westernmost of the studied populations living in the Czech Republic, Slovakia, and Poland can be considered as indigenous and located close to the center of the species range, it can be suggested that their genetic variability, comparable to that in eastern groups, probably indicates that, in 


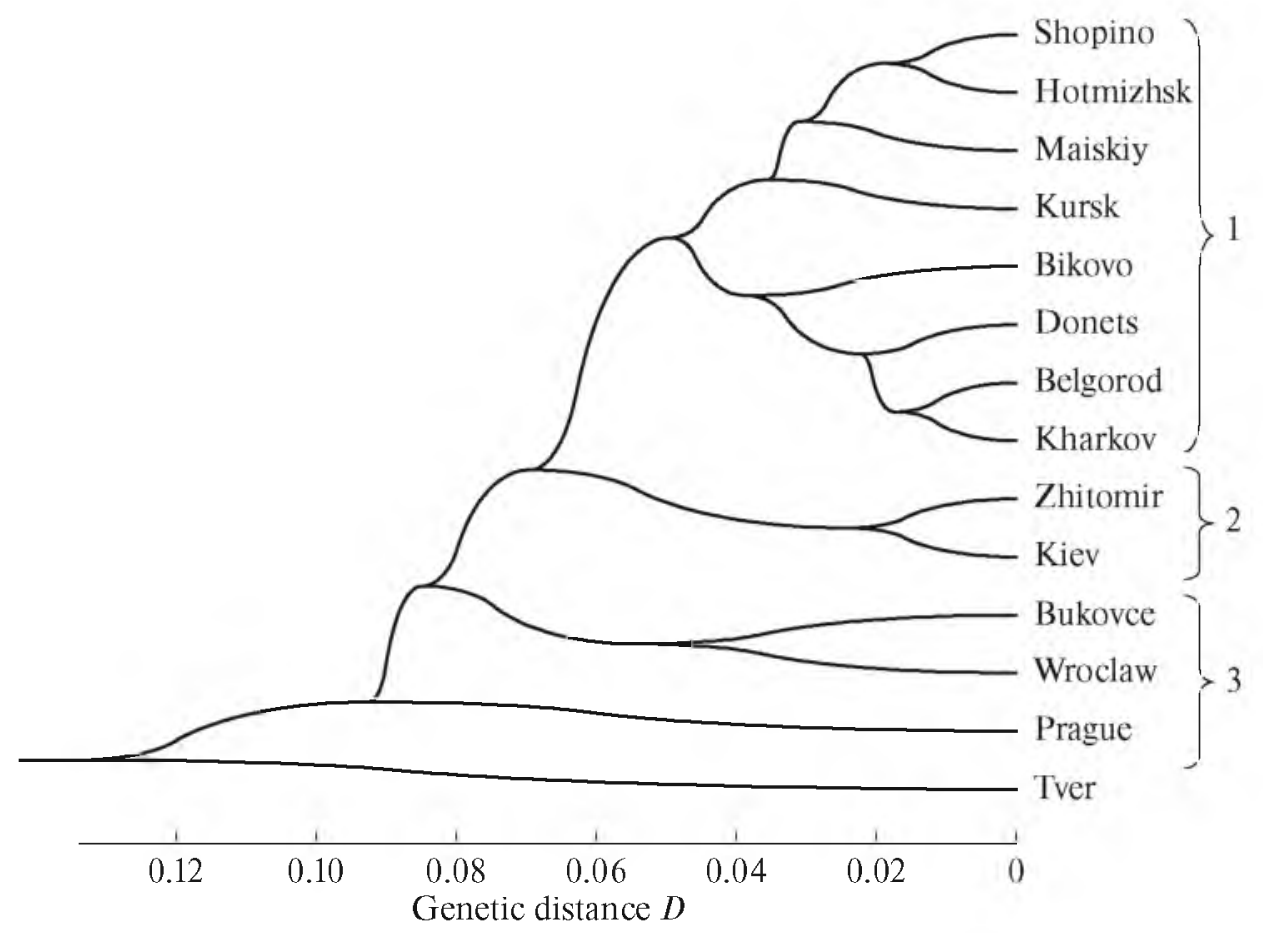

Fig. 3. Dendrogram of Nei genetic distances [40] (UPGMA) between the populations of $H$. pomatia inferred from ISSR marker data (explanations are in the text).

the case of anthropochory, the traditional model implying the decrease in the allele pool in the peripheral groups of $H$. pomatia is disrupted. This phenomenon may be the result of unintentional chaotic introduction of snails (both single individuals and groups) into new territories. It is not excluded that part of the newly formed colonies quickly die out and do not become the objects of observation. At the same time, the surviving colonies after passing through natural selection and the stage of the so-called genetic revolution [44] have formed a balanced genetic system similar to central populations.

It should be noted in this respect that the performance the population genetic heterogeneity indices obtained earlier using allozymes did not correlate with those calculated on the basis of ISSR markers. In particular, the average values of the expected heterozygosity and the Shannon index were lower than the genetic diversity indices revealed by allozyme markers [25]. This fact points to the differences in genetic processes that take place at neutral and selectively important loci.

The observed high level of genetic differentiation in both western and eastern populations, probably, indicates that the previously expressed rule that intrapopulation diversity in the center of the range converts into interpopulation diversity at the periphery of the range [45], in the case of adventitious groups of H. pomatia, is disrupted.
On the basis of sample clustering results and a regression analysis between the pairwise genetic and geographic distances, it can be suggested that the distribution of adventitious populations of $H$. pomatia in the study area is not random and corresponds to the model of isolation by distance, which is characteristic of the selectively neutral genes. In addition, this fact suggests the reduced role of stabilizing selection in the examined Roman snail groups [40]. It seems likely that the dispersal of this species, both natural and anthropochorous, occurs from the neighboring regions, and the oldest populations can serve as so-called dispersal bridgeheads. For example, given the fact that the colony from Kharkiv (site 8 ) has been known since the

Table 6. Effective size values calculated from the linear function coefficients between pairwise gene flow estimates $(\mathrm{Nm})$, and geographic distances between the samples

\begin{tabular}{l|c|l|l|l}
\hline \multirow{2}{*}{ Species } & \multicolumn{2}{|c|}{ Allozymes } & \multicolumn{2}{c}{ DNA } \\
\cline { 2 - 5 } & $N$ & $95 \%, \Delta$ & $N e$ & $95 \%, \Delta$ \\
\hline H. pomatia & $\mathbf{9 . 8}$ & $\mathbf{3 . 9}-\mathbf{2 5 . 1}$ & $\mathbf{3 . 1}$ & $\mathbf{2 . 0}-\mathbf{4 . 9}$ \\
B. fruticum & 4.1 & $2.2-7.6$ & 1.7 & $1.2-2.5$ \\
Ch. tridens & 3.8 & $2.6-5.7$ & 1.2 & $0.8-1.8$ \\
H. striata & 5.1 & $2.6-10.0$ & 1.9 & $1.3-2.7$ \\
\hline
\end{tabular}

The data for Br. fruticum, Ch. tridens, and $H$. striata, as well as for allozymes of $H$. pomatia, are taken from our previous studies [25, $37,41-43]$. 


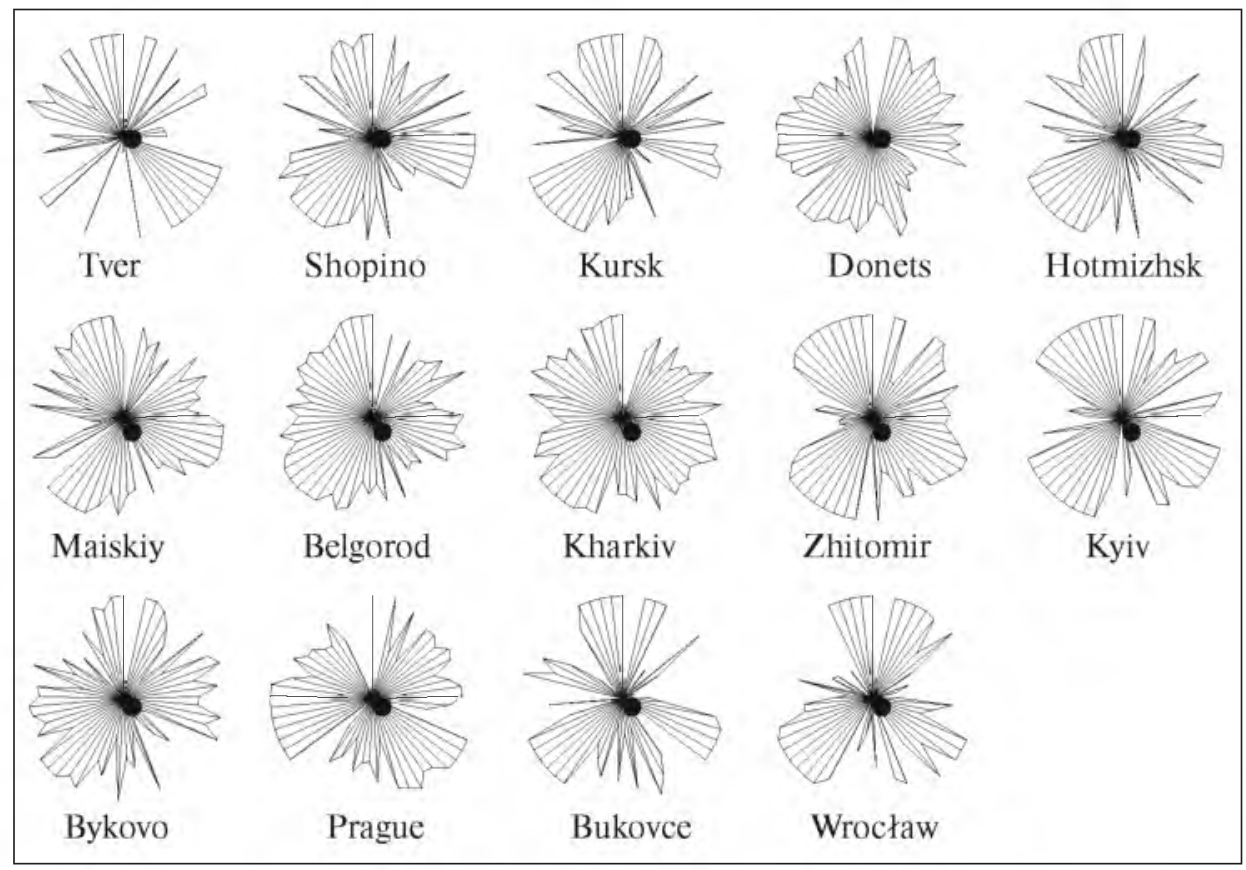

Fig. 4. Debets polygons constructed on the basis of total frequencies of $q$ allele at 57 DNA loci in the populations of $H$. pomatia.

beginning of the 20th century [5], it can be regarded as the maternal group that gave rise to the rest of the colonies from the south of the Central Russian Upland, ${ }^{1}$ which are the members of one relative cluster no. 1 (Fig. 3).

A comparison of the effective population size estimates of $H$. pomatia with similar data for Br. fruticum, $C h$. tridens, and $H$. striata shows a clear increase in the values of this index in the group of Roman snail relative to other species (Table 6). At the same time, the computed confidence intervals show statistically significant differences only between populations of $H$. pomatia and $C h$. tridens at the DNA markers. This result may also indirectly indicate that the effective sizes of adventitious Roman snail groups are comparable to those in indigenous species, both common and relic.

Thus, the data of the present study on the genetic structure of $H$. pomatia obtained on the basis of the ISSR point to the stable state of its gene pool in the more continental climate of Eastern Europe. These findings suggest further expansion of this species in different landscapes, which will be supported by the well-known features of the biology and ecology of these snails, including genetic polymorphism, unpretentiousness to nutrition, reproductive potential,

\footnotetext{
${ }^{1}$ On this territory, since the beginning of 20 th century, there has been one more colony living in the outskirts of the city of Valuiki [4], which is the only one of the studied populations that naturalized in the wild. At present, this population is, probably, in the state of depression, because we found many empty shells and only three living individuals of this species.
}

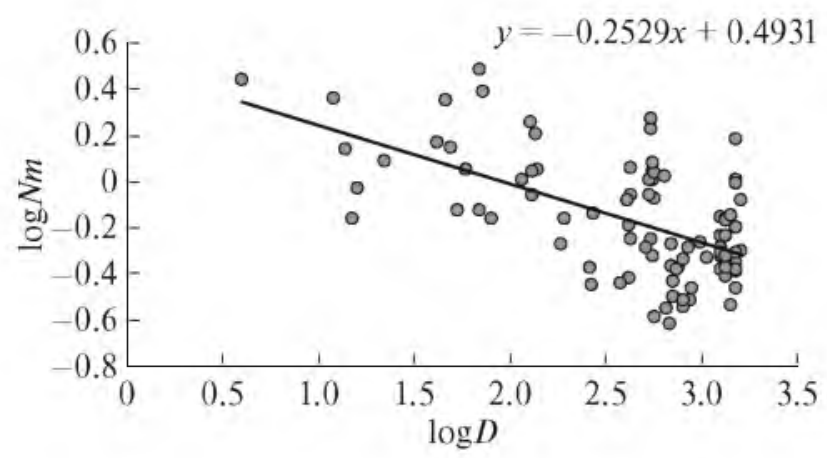

Fig. 5. Dependence of the level of gene flow $\mathrm{Nm}$ between pairs of populations of $H$. pomatia on the geographical distance between them $D(\mathrm{~km})$ (inferred from ISSR marker data).

resistance to pollutants of the urban environment, and effective compensatory genome reactions [37].

\section{ACKNOWLEDGMENTS}

We thank Ondrej Korábek of Charles University in Prague (Czech Republic) for his help in collecting the material.

\section{REFERENCES}

1. Starodubtseva, E.G. and Dedkov, V.P., Grape snail, Helix pomatia L.: spread on the territory of the Kaliningrad oblast, its biotope distribution and the abundance 
estimation, Vestn. Kaliningrad. Gos. Univ., Ser. Ekol. Reg. Balt. Morya, 2003, no. 1, pp. 82-87.

2. Artem'eva, E.A. and Semenov, D.Yu., Grape snail, Helix pomatia L. (Mollusca: Gastropoda: Helicidae)reacclimatized malacofauna species of the Ulyanovsk oblast, Prir: Simbirsk. Povolzh'ya, 2004, no. 5, pp. 6062.

3. Rumyantseva, E.G., Ecological and biological characteristics and the rational use of snail, Helix pomatia L. in the Kaliningrad oblast, Extended Abstract of Cand. Sci. Dissertation, Kaliningrad, 2006, p. 25.

4. Velichkovskii, V., Mollyuski: ocherk fauny Valuiskogo uezda Voronezhskoi gubernii (Mollusks: Essay of Fauna of Valuisky County in the Voronezh Province), Kharkov, 1910 , issue 6.

5. Beletskii, P., Materials to the knowledge of the Russia fauna of Gastropoda mollusks from the Kharkov province, Tr. Kharkov. O-va Ispyt. Prir., 1918, no. 49, pp. $31-42$.

6. Likharev, I.M. and Rammel'meir, E.S., Nazemnye mollyuski fauny SSSR (Terrestrial Mollusks of the Fauna of the Soviet Union), issue 53 of Opredeliteli po faune (Keys to the Fauna), Leningrad: Nauka, 1952.

7. Shileiko, A.A., Nazemnye mollyuski nadsemeistva Helicoidea (Terrestrial Mollusks of the Superfamily Helicoidea), Fauna SSSR: mollyuski (Fauna of the Soviet Union: Mollusks), Leningrad: Nauka, 1978, vol. 3, issue 6.

8. Jarvinen, O., Sisula, H., Varvio-Aho, S.-L., and Salminen, P., Genetic variation in isolated marginal populations of the roman snail Helix pomatia L., Hereditas, 1976, vol. 82, pp. 101-110.

9. Dees, L.T., Edible Land Snails in the United States, US Fish and Wildlife Service, Bureau of Sport Fisheries and Wildlife, 1970, Resource Publication 91.

10. Nekola, J.C., Overview of the North American terrestrial gastropod fauna, Am. Malacol. Bull., 2014, vol. 32, no. 2 , pp. $225-235$.

11. Wells, S.M. and Chatfield, J.E., Threatened nonmarine molluscs of Europe, Nat. Environ., 1992, vol. 64, p. 163.

12. Neubert, E., Helix pomatia, The IUCN Red List of Threatened Species, 2013.

13. Parnikoza, I.Yu., Godlevskaya, E.V., Shevchenko, M.S., and Inozemtseva, D.N., Okhrannye kategorii fauny Ukrainy (Protective Categories of Fauna of Ukraine), Kiev: Kievskii Ekologo-Kul'turnyi Tsentr, 2005.

14. Snegin, E.A., The roman snail, Helix pomatia L., in Krasnaya Kniga Belgorodskoi oblasti: redkie i ischezayushchie rasteniya, griby, lishainiki $i$ zhivotnye (The Red Book of the Belgorod Oblast: the Rare and Endangered Plants, Fungi, Lichens and Animals), Belgorod, 2004.

15. Negrobov, O.P., Krasnaya kniga Voronezhskoi oblasti (The Red Book of the Voronezh Oblast), vol. 2: Zhivotnye (Animals), Voronezh: MODEK, 2011.

16. Sachkova, Yu.V., Fauna and ecology of terrestrial mollusks (Gastropoda, Pulmonata) of forest-steppe of Povolzh'ye (by example of Samara oblast), Extended Abstract of Cand. Sci. Dissertation, Tolyatti, 2006.

17. Pollard, E., Differences in shell thickness in adult Helix pomatia L. from a number of localities in southern England, Oecologia, 1975, vol. 21, pp. 85-92.
18. Khlus, L.M., Khlus, K.M., and Gritsyuk, S.B., Konhological parameters variation in Helix pomatia L. in relation to the level of anthropogenic pressure, Nauk. Visn. Uzhgorod. Nats. Univ., Ser. Biol., 2001, no. 10, pp. $90-93$.

19. Kramarenko, S.S. and Sverlova, N.V., Konhological parameters of the Roman snail, Helix pomatia (Gastropoda, Pulmonata, Helicidae) in the south of Ukraine as a possible consequence of climate selection, Nauk. Zap. Derzh. Prirodozn. Muz., 2005, issue 21, pp. $157-164$.

20. Andreev, N., Assessment of the status of wild populations of Helix pomatia L. in Moldova: the effect of exploitation, CBM Master Theses, 2006, no. 22.

21. Vincent, D. and Magron, J., Esterases (cholinesterase and arylesterase) from hemolymph of Helix pomatia, C. R. Seances Soc. Biol. Ses Fil., 1972, vol. 166, no. 8, pp. 1009-1013.

22. Wahren, H. and Tegelström, H., Polymorphism of esterases and tetrazolium oxidases in the Roman snail, Helix pomatia: a study of populations from Sweden and Germany, Biochem. Genet., 1973, vol. 9, no. 2, pp. $169-174$.

23. Tegelström, H., Häggström, A., and Kvassman, S., Esterases of the snails Helix pomatia and Cepaea hortensis: variation and characterization of different molecular forms, Hereditas, 1975, vol. 79, no. 1, pp. 117-124.

24. Snegin, E.A., Population viability analysis for specially protected species by the example of Helix pomatia L. (Mollusca, Gastropoda, Pulmonata), Teor. Prikl. Ekol., 2010, no. 2, pp. $91-96$.

25. Snegin, E.A. and Artemchuk, O.Yu., Morphogenetic analysis of the Helix pomatia L. (Pulmonata, Helicidae) populations of on the south-eastern and eastern parts of the modern area, Russ. J. Genet.: Appl. Res., 2016, vol. 6 , no. 2 , pp. $152-162$.

26. Zietkiewicz, E., Rafalski, A., and Labuda, D., Genome fingerprinting by simple sequence repeat $(S S R)-$ anchored polymerase chain reaction amplification, Genomics, 1994, vol. 20, no. 2, pp. 176-181.

27. Snegin, E.A. and Artemchuk, O.Yu., Assessment of the grape snail (Helix pomatia L.) population gene pools in urbanized areas using DNA ISSR-markers, Vestn. Tomsk. Gos. Univ.: Biol., 2014, no. 3 (27), pp. 130-141.

28. Excoffier, L., Smouse, P.E., and Quattro, J.M., Analysis of molecular variance inferred from metric distances among DNA haplotypes: application to human mitochondrial DNA restriction data, Genetics, 1992, vol. 131, pp. 479-491.

29. Peakall, R. and Smouse, P.E., GenAlEx 6: genetic analysis in Excel. Population genetic software for teaching and research, Mol. Ecol. Notes, 2006, vol. 6, pp. $288-295$.

30. Mantel, N., The detection of disease clustering and a generalized regression approach, Cancer Res., 1967, vol. 27, pp. 209-220.

31. Diniz-Filho, J.A.F., Soares, T.N., Lima, J.S., et al., Mantel test in population genetics, Genet. Mol. Biol., 2013, vol. 36, no. 4, pp. $475-485$.

32. Nei, M. and Li, W.H., Mathematical model for studying genetic variation in terms restriction endonucleases, 
Proc. Natl. Acad. Sci. U.S.A., 1979, vol. 76, pp. 52695273.

33. Nei, M., Estimation of average heterozygosity and genetic distance from a small number of individuals, Genetics, 1978, vol. 89, pp. 583-590.

34. Tamura, K., Stecher, G., Peterson, D., et al., MEGA6: Molecular Evolutionary Genetics Analysis version 6.0, Mol. Biol. Evol., 2013, vol. 30, pp. 2725-2729.

35. Nei, M., Molecular Population Genetics and Evolution, Amsterdam, 1975.

36. Yeh, F.C., Yang, R., Boyle, T.J., et al., POPGENE. Microsoft Windows-Based Freeware for Population Genetic Analysis: Release 1.32, Edmonton: Molecular Biology and Biotechnology Centre, University of Alberta, 2000. http://www.ualberta.ca/ fyeh/popgene_download.html.

37. Snegin, E.A., Spatial and temporal aspects of the ecological and genetic structure of invertebrate populations (on the example of terrestrial mollusks and insects in the south of the Central Russian Upland), Doctoral (Biol.) Dissertation, Belgorod: Belgorod Gos. Univ., 2012.

38. Snegin, E.A., Status assessment of the population gene pools of specially protected species Helicopsis striata (Mollusca, Gastropoda, Pulmonata) using DNAmarkers, Ekol. Genet., 2015, vol. 13, no. 3, pp. 28-39.

39. Dinamika populyatsionnykh genofondov pri antropogennykh vozdeistriyakh (Dynamics of Population Gene
Pools under Anthropogenic Impact), Altukhov, Yu.P., Ed., Moscow: Nauka, 2004.

40. Slatkin, M., Isolation by distance in equilibrium and non-equilibrium populations, Evolution, 1993, vol. 47, no. 1, pp. 294-279.

41. Snegin, E.A., The genetic structure of model species populations of terrestrial mollusks in conditions of urbanized landscape using the example of Chondrula tridens Müll (Gastropoda, Pulmonata), Russ. J. Genet.: Appl. Res., 2012, vol. 9, no. 2, pp. 160-170.

42. Snegin, E.A., Analysis of genetic variability of the terrestrial mollusk Bradybaena fruticum Müll. populations using RAPD and ISSR markers, Nauch. Vedomosti Belgorgd. Gos. Univ., Ser. Estestv. Nauki, 2011, no. 15 (110), issue 16, pp. 37-43.

43. Snegin, E.A., Analysis of genetic variability in populations of a terrestrial snail Chondrula tridens Müll. (Gastropoda, Pulmonata), based on the RAPD and ISSR markers, Russ. J. Genet.: Appl. Res., 2014, vol. 4, no. 5 , pp. 444-454.

44. Mayr, E., Animal Species and Evolution, Cambridge: Belknap, 1963.

45. Timofeev-Resovskii, N.V., Yablokov, A.V., and Glotov, N.V., Ocherk ucheniya o populyatsii (An Essay on Population), Moscow: Nauka, 1973.

Translated by N. Maleeva 